\title{
Leopoldo María Panero, deconstructor de leyendas épicas familiares
}

A propósito de El desencanto (1976) de Jaime Chávarri

\section{Antonia Del Rey-Reguillo}

\section{(2) OpenEdition}

\section{Journals}

Edición electrónica

URL: http://journals.openedition.org/agedor/590

DOI: $10.4000 /$ agedor.590

ISSN: 2104-3353

\section{Editor}

Laboratoire LISAA

Referencia electrónica

Antonia Del Rey-Reguillo, «Leopoldo María Panero, deconstructor de leyendas épicas familiares », L'Âge d'or [En línea], 7| 2014, Publicado el 01 marzo 2014, consultado el 01 mayo 2019. URL : http:// journals.openedition.org/agedor/590; DOI : 10.4000/agedor.590 


\title{
Leopoldo María Panero, deconstructor de leyendas épicas familiares. A propósito de El desencanto (1976) de Jaime Chávarri
}

\begin{abstract}
Résumé : L'entreprise pour faire tomber les masques de la famille Panero accomplie par le film El desencanto de Jaime Chávarri, transforma sa sortie - à l'automne 1976 - en une sorte de séisme pour la société espagnole de l'époque. Cela donna lieu à de nombreuses lectures du film, qui finit par être vu comme une métaphore de la Transition. Aujourd'hui, presque quatre décennies plus tard, il semble nécessaire d'aborder son étude depuis de nouvelles perspectives. L'une d'elles repose sur son analyse textuelle qui met en évidence la stratégie du réalisateur pour convertir Leopoldo María Panero en l'élément central de son film, vu les affinités intellectuelles et les points de vue qu'ils partageaient, entre autres, le thème des relations de domination qui s'exercent dans l'environnement familial. Cela explique comment dès les premières minutes du film, le discours filmique a fait du jeune novisimo et de son point de vue radical l'axe fondateur du récit.
\end{abstract}

Mots-clés : Jaime Chávarri - Leopoldo María Panero - famille - discours filmique - figure maternelle - figure paternelle-déconstruction

Resumen: La operación de desenmascaramiento de la familia Panero practicada por la película El desencanto de Jaime Chávarri, convirtió su estreno -otoño de 1976- en una suerte de seísmo para la sociedad española del momento. Ello propició numerosas lecturas del filme, que acabó siendo visto como una metáfora de la Transición. A día de hoy, transcurridas casi cuatro décadas desde entonces, parece necesario abordar su estudio desde nuevas perspectivas. Una de ellas la propicia el análisis textual. Mediante él se evidencia la estrategia del realizador para convertir a Leopoldo María Panero en el elemento central de su película, dada la afinidad de temas y puntos de vista que ambos compartían, entre ellos, el de las relaciones de dominación habidas en el ámbito familiar. Solo así se explica que el discurso fílmico, ya desde los primeros minutos, convierta al joven novísimo y su radical punto de vista en los ejes del relato.

Palabras clave: Jaime Chávarri - Leopoldo María Panero - familia - discurso fílmico - figura materna - figura paterna - deconstrucción

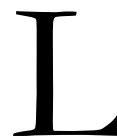

a imagen de Leopoldo María, el segundo de los hermanos Panero, hace acto de presencia en la película El desencanto desde el primer segundo, como las del resto de los miembros de la familia, aunque posteriormente su figura se resistirá a aparecer. Durante el minuto y medio escaso que dura la secuencia de créditos, inscritos sobre el fondo de una fotografía familiar tomada a principios de los años cincuenta, el niño Leopoldo -reconcentrado y un punto triste-, situado a la derecha del grupo que componen los tres hermanos, se nos muestra como uno de los vértices del triángulo filial que, junto a la madre, dará vida al relato. Anticipado desde la instantánea el personaje plural protagonista del relato, todo invita a pensar que la presencia de las 
individualidades que lo componen se irá dando cita en la película de forma simultánea o alternada, pero las cosas no serán exactamente así y la ausencia del segundo de los hermanos se dejará sentir durante la primera mitad de la película. Sin embargo su no presencia es solo aparente, ya que dicho personaje sobrevuela el discurso fílmico en todo momento, incluso antes de que su figura tome la palabra. A partir de entonces sus intervenciones resultarán determinantes, como una vuelta de tuerca que logra disparar el sentido del relato en nuevas direcciones. [Fig. 1]

El estreno de la película en 1976, meses después de la muerte del dictador Francisco Franco, supuso una fuerte conmoción y la dotó de un valor simbólico innegable, propiciando un torrente de escritos interpretativos y que tanto el director como los protagonistas fueran sometidos a numerosas entrevistas orientadas a conocer de primera mano las circunstancias que rodearon la ideación y producción del filme ${ }^{1}$. La suma de todo ello acabaría acuñando la lectura ortodoxa de El desencanto como metáfora del proceso político de la transición, lectura que permanece vigente en nuestros días. Sin embargo, las casi cuatro décadas transcurridas desde entonces han alumbrado nuevos y serios trabajos que aportan datos sustanciales sobre el autor y los personajes -con Leopoldo María a la cabeza- suscitando nuevas aproximaciones críticas a la película ${ }^{2}$. En esa línea de revisión interpretativa sitúo el objetivo de este artículo, donde intentaré demostrar cómo el director selecciona y organiza cuidadosamente el metraje filmado con el objeto de erigir a Leopoldo María Panero en protagonista indiscutible de la cinta y ello, porque las afinidades que el cineasta detectó entre sus propios intereses y el discurso del poeta resultarían determinantes para ayudarle a sustanciar su proyecto de filme. Tanto los encuentros previos al rodaje habidos con Leopoldo, en cuyas obsesiones e intereses de entonces Chávarri se reconoce, como las posteriores declaraciones del poeta ante la cámara, empujaron al cineasta a convertir su persona y su discurso en ejes del relato. De este modo, la confluencia de intereses entre el director y su personaje acabaría resultando una fórmula perfecta para indagar en el tema de las relaciones familiares, que, por su poder dominador sobre el individuo, Chávarri equiparaba a las que se establecen entre el estado y los ciudadanos ${ }^{3}$.

\section{Una gestación dificultosa}

En el libro que recoge el guion de la película el realizador revela cómo, pese a las muchas horas de conversaciones y grabaciones habidas con Leopoldo, éste se negaba en redondo una y otra vez a hablar ante la cámara y solo Elías Querejeta, productor del filme, fue capaz de hacerle cambiar de opinión ${ }^{4}$. Concebida en una primera instancia como un cortometraje, la cinta debía centrarse en la figura del padre de familia, el reconocido poeta

\footnotetext{
1 Todas ellas quedaron expuestas por Chávarri en la memoria del rodaje contenida en el libro sobre la película editado por Elías Querejeta en paralelo a su estreno.

${ }^{2}$ Uno de los estudios recientes más destacados es el de Juan Egea, para quien la película « representa menos un momento histórico que los modelos interpretativos a los que ha dado lugar». En EGEA, Juan, «El desencanto: la mirada del padre y las lecturas de la Transición », en Symposium, 2004, no 58, vol. 2, p. 79.

3 ALVARES, Rosa y ROMERO, Antolín, Jaime Chávarri. Vivir rodando, Valladolid, Semana Internacional de Cine, 1999 , p. 51.

4 Según el director, aunque Leopoldo se prestó a ser filmado en el cementerio de Loeches para el cortometraje originario de la película, posteriormente, cuando ésta pasó a concebirse como un largometraje, opondría mucha más resistencia. En BLANC, Felicidad, PANERO, Juan Luis, PANERO, Leopoldo $\mathrm{M}^{\mathrm{a}}$ y PANERO, José Moisés, El desencanto, Madrid, Elías Querejeta Ediciones, 1976, p. 139 y 142.
} 
Leopoldo Panero. A partir de esa premisa, supuestamente, la trayectoria vital y creadora del escritor quedaría dibujada " a través de las miradas de su viuda y sus hijos ${ }^{5}$-Felicidad Blanc, Juan Luis, Leopoldo María y Michi- mediante sucesivas conversaciones mantenidas ante la cámara con todos ellos. No existía ni guion ni plan previo para dotar de orden al relato, sino la voluntad de que cada miembro de la familia se expresara a su antojo. Según Chávarri, los Panero no confiaban demasiado en el proyecto. Para ellos parecía ser una suerte de juego en el que habían aceptado participar asumiendo, eso sí, las " dos reglas fundamentales que lo condicionaban todo : hasta que acabara el film, nadie sabría lo que decían los demás; y si el trabajo no gustaba a la familia, la película no existiría $»^{6}$.

Tras las primeras filmaciones, director y productor percibieron la necesidad de ampliar el proyecto inicial y convertirlo en un largometraje que diera cabida al valioso material proporcionado por los Panero. Sobre él, Chávarri acabaría operando una selección mediante la que lograr la progresión narrativa que, en buena medida, se iría ordenando a sí misma. Hasta llegar a darle forma, el recorrido iba a resultar más que tortuoso. De hecho, desde un principio las sesiones de trabajo con los miembros de la familia resultaron bastante ingobernables, lo que acabaría alargando mucho el tiempo del rodaje : «Durante un año el rodaje entraba y salía de la vida de quienes trabajaban en el proyecto. El tiempo transcurrido entre sesión y sesión hacía que cambiaran las circunstancias personales, el estado de ánimo, la estrategia ante la cámara y hasta el peinado de los integrantes de la familia $»^{7}$.

Una filmación tan discontinua terminó por evidenciar contradicciones en las opiniones expresadas por los protagonistas y sorprendentes cambios de postura ante los temas que iban tratando y las alianzas y complicidades que establecían entre ellos. Así, el material filmado resultante de aquellas sesiones supuso un desafío para el realizador que, sin duda alguna, mediante el montaje supo manejarlo construyendo un discurso orientado en la dirección que más le interesaba hasta dotarlo de un potencial significativo cuyo alcance ni siquiera él mismo podía sospechar. Y es que la imposición de la voluntad rectora en el proceso de edición, como prerrogativa innegable de todo realizador, no por obvia es menos reveladora en el caso del El desencanto y acabaría resultando determinante por lo que al papel de Leopoldo María se refiere, no sólo por los fragmentos que Chávarri selecciona de entre todo el material filmado, sino, esencialmente, por el orden en que los exhibe a lo largo de la película.

Entre los meses de septiembre de 1974 y 1975, el año de trabajo intermitente habido con los Panero había proporcionado al director siete horas de filmación, un metraje muy abundante del que sólo precisaba noventa minutos para su documental. Y el director utilizaría sus tijeras con pulso firme, hasta obtener la suma de segmentos precisa con la que componer el puzle de celuloide acorde con sus intereses. En aquel momento éstos estaban claramente orientados hacia el tema de las relaciones familiares, un asunto sobre el que Chávarri ya había puesto el foco al realizar Los viajes escolares, su película inmediatamente anterior. El propio director confesaría más de veinte años después, que tanto en aquella película como en El desencanto quiso contar el enorme poder que la familia ejerce sobre los miembros que la componen : «(...) el poder de la familia es igual que el poder del Estado o cualquier otro. Hay un momento en que tienes que romper, o al menos rebelarte contra esa

\footnotetext{
${ }^{5}$ Ibid., p. 139.

6 ALVARES, Rosa y ROMERO, Antolín, Jaime Chávarri. Vivir rodando, op. cit., p. 62.

${ }^{7}$ Ibid, p. 62.
} 
tiranía. Para mí, contarlo era una cuestión de salud mental. Quizá por esa tontería que te entra a los veinte años, que en mi caso eran casi treinta... $»^{8}$.

Así las cosas, las confesiones de los miembros de la familia Panero le resultarán un material muy rico y sumamente idóneo para profundizar en el tema. Ningún guion imaginable habría sido capaz de componer unos personajes tan complejos, variopintos y singulares como el trío de hermanos que, junto a la madre, iban a ser capaces de desnudarse frente a la cámara a golpe de palabras, dejando al descubierto las oscuras interioridades de su, al menos en apariencia, respetable familia burguesa. Tampoco Chávarri sospechaba el alcance de su atrevimiento, ni las notables dotes de los Panero para desenvolverse ante la cámara con total naturalidad y transformarse con acierto en las dramatis personae del relato?.

Para preparar el documental, el realizador había celebrado diversas entrevistas con casi todos ellos ya en los inicios del proyecto, durante el verano de 1974, cuando aquel solo tenía carácter de cortometraje. Así obtuvo horas de grabaciones en cinta magnetofónica donde quedaron registradas las conversaciones. Sin embargo, para ese primer contacto Leopoldo María se hizo esperar y, en tanto que llegaba, Chávarri, que solo conocía de vista al joven novísismo, tuvo que soportar las voces familiares que zumbaban en torno a él con preocupantes advertencias : "Con Leopoldo es difícil hablar, te vas a volver loco con Leopoldo, Leopoldo no querrá, ya verás qué problemas plantea Leopoldo ${ }^{10}$. Con aquellos comentarios y probablemente sin pretenderlo, la familia estaba potenciando el interés del director por el huidizo personaje y es fácil imaginar la expectación con la que debió saludarlo meses después, cuando finalmente logró tener la primera entrevista con quien por entonces ya poseía cierta aureola de leyenda derivada de su extravagante conducta ${ }^{11}$.

Pese a las reticencias iniciales del poeta, Chávarri consiguió grabar horas y horas de cinta durante sus encuentros, aunque sin entrar en recuerdos familiares, pues Leopoldo no creía en el proyecto del director madrileño - estaba convencido de que nadie diría la verdad- y eran otros los temas que lo absorbían, como la psicología, la filosofía y el simbolismo. Y en ellos se centraron las conversaciones. Pese a todo, esos primeros encuentros acabarían siendo productivos y en extremo determinantes para la futura película: el realizador no solo arrancaría del díscolo poeta la promesa de recitar en un cementerio, sino que percibió en él un tipo de testimonio que marcaba la diferencia con el resto de su familia y atrajo su atención. De algún modo, Chávarri llegó a sentirse cómodo hablando con él ya en aquellas primeras citas y, en las sesiones posteriores, entre ambos debió surgir una progresiva sintonía derivada del común interés que los dos sentían tanto por el psicoanálisis como por la antipsiquiatría y el mundo de la demencia ${ }^{12}$.

\footnotetext{
8 Ibid, p. 51.

9 Aunque, en última instancia, la película era deudora de la amistad entre Chávarri y Michi, el menor de los hermanos Panero, el realizador no los conocía tanto como para suponer la gran implicación que ellos asumirían con el rodaje. De ahí su asombro : «Los Panero se mueven ante la cámara como pez en el agua. Felicidad es la única que prepara un poco sus intervenciones. Juan Luis colabora, incluso, en la puesta en escena de sus propias secuencias ». En BLANC, Felicidad, PANERO, Juan Luis, PANERO, Leopoldo $\mathrm{M}^{\mathrm{a}}$ y PANERO, José Moisés, El desencanto, op. cit., p. 139.

10 Ibid., p. 138.

${ }^{11}$ En los círculos intelectuales de su generación eran bien conocidos los excesos de conducta que Leopoldo María se autoinfligía. Su propio hermano Michi se encargaba de pregonarlos : «Cada vez que ve aparecer a su hermano por la terraza del Dickens, Michi brama : 'Viene Tiburón Panero', en clara alusión al personaje de James Bond ». En FERNÁNDEZ, J. Benito, El contorno del abismo. Vida y leyenda de Leopoldo María Panero, Barcelona, Tusquets, 2006, p. 171.

12 Antes de su proyecto sobre Panero, el realizador planeó el rodaje de un corto en un manicomio para servirse solo de las imágenes y los sonidos allí captados y prescindir de los comentarios en voz over, pero no obtuvo permiso. Décadas después de filmar El desencanto, él mismo confesaría cómo había estado haciendo
} 
En cualquier caso, Leopoldo María era inaprensible y sus constantes ausencias, unidas a la actitud del resto de la familia contribuían a aumentar la zozobra del director. La descripción de sus sentimientos de marzo de 1975 así lo corrobora : «Creo que voy hacia el caos, que no existe nada que ligue todo lo que estoy rodando. No me siento capaz de controlar a los Panero, ellos se apoyan entre sí y yo estoy cabreado y, lo que es peor, inseguro. Ellos parecen seguir convencidos de que todo es un disparate $»^{13}$. Así las cosas, cuando seis meses después el segundo de los hermanos acepte participar en el rodaje, la película entrará en su recta final y el trabajo realizado empezará a cobrar sentido. Como el resto de su familia, es el propio Leopoldo María el que elige los escenarios en los que filmar las dos sesiones de rodaje que tiene pendientes y opta por el colegio de su infancia, el Liceo Italiano, en cuyo jardín se fraguan sus intervenciones de forma completamente improvisada y con una sinceridad que sorprende y que, en última instancia, desarma el discurso de sus interlocutores, Felicidad y Michi. El colofón de sus intervenciones se sucede en un bar restaurante al que acudieron también varios amigos del poeta y donde éste disertó ampliamente sobre los temas que lo obsesionaban: el alcohol, la cárcel, la destrucción, el padre y, cómo no, el psicoanálisis ${ }^{14}$.

Obviamente, las siete horas de película grabadas con los Panero constituían material suficiente para permitir al director haber realizado una selección de metraje distinta y adoptar otras opciones de montaje. Así pues, es lícito preguntarse por las razones que determinaron las elecciones que darían como resultado la película definitiva. En parte, la respuesta a esta cuestión la dio el propio realizador al describir sus impresiones en los momentos finales del montaje : "Los últimos rodajes con Leopoldo han resultado fundamentales para la película terminada. Son el pivote de la segunda mitad. Felicidad y Juan Luis dominan la primera parte y Michi, más distante, interpreta una especie de moderador provocador $\gg$. Con sus declaraciones el director parece sugerir una participación equilibrada y un protagonismo equiparable de todos los miembros de la familia, sin embargo, las imágenes y los diálogos de la película demuestran que, desde su posición de supremo hacedor, Chávarri privilegió la figura y el testimonio de Leopoldo María sobre las del resto de sus familiares, que, en mayor o menor medida, funcionaron casi como comparsas del personaje central. La madre en su doble papel de tejedora del marco de recuerdos familiares y de replicante frente a los embates de su segundo hijo; Michi, como provocador y árbitro de las conversaciones; y Juan Luis, travistiéndose de payaso simulador para definirse a sí mismo mientras invoca la figura paterna.

En efecto, la presencia del segundo de los hermanos Panero está totalmente medida en el filme y sus apariciones, en forma de alusiones verbales de su madre y hermanos o de imágenes propiamente dichas, surgen diseminadas cuidadosamente a lo largo del relato al tiempo que adquieren un peso dramático creciente hasta dominar con claridad los intercambios dialogados habidos en la segunda mitad de la película, cuando Leopoldo María se convierte en el protagonista indiscutible de la película.

autopsicoanálisis durante muchos años y cómo, tras el estreno del filme, estuvo acudiendo durante un año a un psiquiátrico donde se practicaban los principios de la antipsiquiatría siguiendo las directrices de Ronald Laing. En ALVARES, Rosa y ROMERO, Antolín, Jaime Chávarri. Vivir rodando, op. cit., pp. 53 y 73.

13 En BLANC, Felicidad, PANERO, Juan Luis, PANERO, Leopoldo $\mathrm{M}^{\mathrm{a}}$ y PANERO, José Moisés, El desencanto, op. cit., p. 142.

${ }^{14}$ En FERNÁNDEZ, J. Benito, El contorno del abismo, op. cit., p. 193-194.

15 En BLANC, Felicidad, PANERO, Juan Luis, PANERO, Leopoldo M y PANERO, José Moisés, El desencanto, op. cit., p. 144. 


\section{Voces, poses y polémicas familiares}

Esa voluntad privilegiadora del director explicaría que el nombre de Leopoldo María irrumpa ya en los primeros minutos del metraje propiciando todo tipo de incógnitas sobre el significado de la película. Previamente, el documental ha dado cuenta de la inauguración de un monumento en memoria del poeta padre, erigido en su ciudad natal ante la presencia de su esposa e hijos, excepto Leopoldo María (presumiblemente en la mente de todos los espectadores en razón de su ausencia). Inscrita sobre las imágenes de la ceremonia, la voz de Felicidad Blanc evoca el momento de la muerte del poeta. De sus expresiones se desprende cierta nostalgia : "Los días anteriores habíamos sido felices ». Dando voz a la madre en primer lugar, el realizador otorga a su personaje una relevancia sustancial, aceptando que su punto de vista marque inicialmente la dirección del relato. De ahí que interrumpa las imágenes de la ceremonia para mostrarnos a Felicidad en el interior de la casa familiar narrando frente a su hijo pequeño lo que para ella representó vivir en la provincia, alejada de su cotidianeidad madrileña. Y, por lo mismo, al retomar las imágenes del homenaje, la voz de la mujer describiendo su difícil encaje en la vida astorgana vuelve a sonar serena y firme sobre ellas, imponiendo un plus de significado ${ }^{16}$. Estas secuencias introductorias, además de anticipar el peso considerable que la figura materna tendrá en la película, suponen la negación del personaje del padre -y supuesto centro del relato- cuya estatua representativa mostrada en primer plano, literalmente velada por un lienzo de plástico sujeto con una cuerda, abre el relato aportando cierto suspense y funcionando a modo de MacGuffin para disparar las inferencias espectatoriales, aunque, como se comprobará después, sin que en sí misma constituya el elemento dramático principal ${ }^{17}$.

$\mathrm{Y}$ es que, de inmediato y sin solución de continuidad, el discurso fílmico deja al descubierto su verdadero centro de interés. Sin imagen que lo represente, el que a partir de ese momento será personaje central, hace acto de presencia al ser nombrado. Tan solo han transcurrido cinco minutos de película ${ }^{18}$ cuando, abruptamente y sin que nada permita imaginarlo, el parlamento que inicia Michi Panero, sentado frente a su hermano Juan Luis en el pequeño jardín de la casa familiar, plantea una pregunta clave :

Lo que me gustaría saber es exactamente (...) qué sería de este rodaje (...) no solo del rodaje sino de la película, del hecho de la película en sí, si hubiera existido como una persona presente durante toda la elaboración, el rodaje, las discusiones, etc., etc... mi hermano Leopoldo, que es uno de los temas indudablemente más importantes de la película. Vamos,

\footnotetext{
$16 \mathrm{El}$ hecho de que Felicidad Blanc fuera el único miembro de la familia en preparar su actuación ante la cámara y en redactar las ideas y temas del discurso ha propiciado interpretaciones del filme como la de Jo Labany, para quien la película se puede leer como « el drama, no del amor-odio de los hijos hacia la figura fantasmal del padre muerto, sino de la relación conflictiva entre madre e hijos », esencialmente la mantenida con Leopoldo María. Véase LABANY, Jo, «Los fantasmas del pasado y las seducciones del psicoanálisis : El desencanto (Jaime Chávarri, 1976) », en Palacio, Manuel, El cine y la transición política en España (1975-1982), Madrid, Biblioteca Nueva, 2011, p. 77.

${ }^{17}$ El significado simbólico de la estatua paterna oculta por el envoltorio de plástico constituye otro de los ejes interpretativos de la película más recurrentes. Al respecto, Jaime Chávarri ha declarado repetidamente que con esas imágenes del padre atado y oculto solo buscaba expresar su imposibilidad para defenderse de los ataques filiales.

18 Se trata de la primera alusión a Leopoldo María y se produce exactamente a los cinco minutos y diecisiete segundos del metraje.
} 
que significa o cristaliza la ruptura de una serie de cosas, más que la muerte de papá, el hecho de Leopoldo que me parece que es una cosa bastante obvia ${ }^{19}$.

$\mathrm{Al}$ insertar en un momento tan temprano el nombre de Leopoldo María unido a las reflexiones subsiguientes, la enunciación del relato fílmico evidencia sin ambages su intención de focalizar el discurso en dicho personaje. Y la inclusión de un plano de Juan Luis levantando las cejas y frunciendo la frente con asombro e incredulidad en el momento en que escucha el nombre de Leopoldo María no hace sino subrayarla. [Fig. 2] Su gesto algo histriónico no solo acentúa el futuro peso dramático del segundo de los hermanos, sino que insinúa cierto desafecto hacia él y anticipa los futuros enfrentamientos y discrepancias que el hermano mayor sostendrá con Michi por su causa.

La polémica entre ambos, a propósito de Leopoldo María, surge de inmediato. Además de denunciar la ausencia de diálogo familiar habida con él, Michi lo califica de 'personaje molesto', recordando las constantes discusiones mantenidas por su causa en el seno de la familia. Y es entonces -ya cumplidos los seis minutos de película- cuando la figura del novísimo hace acto de presencia deambulando entre las tumbas de un cementerio $^{20}$. Sin pronunciar palabra y mirando a la cámara con rostro serio, su aparición tiene algo de espectral y coincide con un momento muy tenso de la discusión fraterna en torno a su persona. [Fig. 3] Los veintiocho segundos de su deambular sirven para descubrir a un Leopoldo María que no habla, sino que 'es hablado' por sus hermanos, aunque se ha convertido en el centro de la secuencia. Ésta concluye significativamente cuando Michi lanza una fuerte andanada contra la familia Panero : "Todo lo que yo sé sobre el pasado, el presente y el futuro de la familia Panero es que es la sordidez más puñetera que he visto en mi vida ». De este modo, la descalificación que el pequeño de los hermanos hace de la familia común queda asociada de algún modo a la figura del hermano ausente, de la que el relato parece no poder sustraerse.

En las siguientes secuencias vuelven a tomar la palabra Juan Luis y Michi, juntos o por separado. Ambos representan sus particulares performances mientras se autorretratan en el marco de la familia Panero ${ }^{21}$. En alternancia con ellos concurre Felicidad para seguir evocando su juventud madrileña interrumpida por la Guerra Civil y la convivencia con su marido y su cohorte de amigos poetas en los primeros años de matrimonio. Sin embargo, no transcurre mucho tiempo cuando el nombre de Leopoldo María es invocado de nuevo por Michi al cuestionarse cómo habría aceptado su padre el proceso vivido por Leopoldo María $^{22}$. La respuesta de Juan Luis es contundente: lo habría aceptado muy mal. Estas últimas referencias a la figura del novísimo suman nuevos detalles con los que el segundo de los hermanos se va perfilando como un elemento problemático para la convivencia familiar. Acto seguido tanto Felicidad como Juan Luis se esfuerzan por dibujar el perfil humano y artístico del padre difunto con todas sus contradicciones, aunque en realidad terminan hablando de sí mismos. En el momento de evocar las circunstancias que rodearon

\footnotetext{
${ }^{19}$ El parlamento de Michi Panero está tomado de la copia de la película. La edición del guion de la película hecha por Elías Querejeta refleja los diálogos con bastante exactitud, aunque con respeto a este parlamento se observan pequeños cambios.

${ }^{20}$ Exactamente, la imagen del segundo de los hermanos toma forma en la película a los seis minutos y cuarenta y dos segundos del inicio de la cinta.

${ }^{21}$ El alto grado de ironía, lucidez y autorreflexividad del filme ha sido señalado por Juan Egea al afirmar que los mismos protagonistas parecen ser muy conscientes « del valor simbólico o de la simbolización a la que va a ser sometido », produciendo la impresión de que todo sea una pose en la que los personajes se interpretan a sí mismos. En EGEA, Juan, « El desencanto: la mirada del padre y las lecturas de la Transición », op. cit., p. 87. 22 Es la tercera alusión a su persona, en este caso solo verbal, cuando se cumplen veintiséis minutos y cincuenta y tres segundos de película.
} 
su muerte, Felicidad recuerda el sueño que tuvo pocos días antes del suceso. Comenta que se le había repetido dos veces y en él « yo aparecía en una calle llena de gente llevando a mi niño de la mano, a Leopoldo María, y yo lloraba de una manera tremenda, lloraba desesperada con el niño de la mano ». Es decir, el nombre del hijo ausente irrumpe por cuarta vez desde el inicio del relato, ${ }^{23}$ desvelándose como una presencia inevitable que en este caso, además, va vinculada a las lágrimas de la madre y a la muerte del padre, en una vaga premonición no solo de la desdicha familiar que estaba por llegar, sino de los desencuentros maternofiliales que en el futuro serían una constante entre el poeta novísimo y su progenitora.

La narración de la muerte del padre y la nueva vida familiar en Madrid supone la conclusión de la primera parte de la película y de las intervenciones de Juan Luis. A partir de ese momento -cumplidos cuarenta y cinco minutos del metraje- el personaje de Leopoldo María empieza a gobernar el relato. Su nombre y su persona vuelven a ser invocados, ahora con intensidad creciente, en la conversación mantenida entre Felicidad y Michi. Se trata de un largo parlamento donde ambos reflexionan sobre la conflictiva relación habida entre los hermanos mayores. Lo inicia Michi señalando la capacidad de Leopoldo María para alterar la convivencia familiar tras la desaparición del padre: «Esto funciona bien a medias. Funciona bien seis meses o siete hasta que Leopoldo realmente se convierte en una amenaza en potencia ; luego el tiempo demostraría que sí era tal amenaza contra la carrera literaria de Juan Luis ». Ajustadas por montaje a las palabras de Michi van sucediéndose tres fotografías infantiles del novísimo, de recién nacido (cuando se pronuncia su nombre), con el brazo en alto (mientras se escucha la palabra "amenaza») y tomando una papilla en los brazos de su madre ante la mirada atenta de Juan Luis (cuando el término «amenaza» suena por segunda vez). Las tres imágenes vienen a subrayar la fuerte impronta que, ya desde su infancia, tuvo el segundo hermano en el seno de la familia y anuncian el desencuentro permanente habido entre él y el hermano mayor. A partir de ese momento Michi reconoce la supremacía pública de Leopoldo María: « no porque Leopoldo escribiera o dejara de escribir, sino porque va haciendo una serie de cosas que no había hecho antes Juan Luis, quizá por falta de valor », y decididamente toma partido por él al juzgar su escritura más interesante que la de aquél. Sus palabras son ilustradas con tres nuevos insertos de fotos donde se dan citas los niños Panero, la última de ellas, con el rostro de un Juan Luis adolescente profundamente serio. Por su parte, Felicidad señala cómo fue su segundo hijo quien le hizo tomar contacto con una realidad para ella desconocida y a la que tuvo que adaptarse, reconociendo con ello el poder de su vástago para transformar no solo la visión del mundo, sino la propia conducta materna. La secunda Michi cuando confiere a Leopoldo la constancia en sus actividades y la autenticidad de conducta de la que carecieron tanto él como Juan Luis, incluso en sus intentos de suicidio, alejados de las simples poses literarias.

\section{Ceremonia de deconstrucción}

Mediante la estrategia narrativa descrita hasta aquí, Chávarri no solo logra dirigir las inferencias espectatoriales hacia el personaje que más le interesa, sino suscitar considerable expectación en torno a él, pues, por lo visto y escuchado, queda meridianamente claro que

\footnotetext{
${ }^{23}$ Exactamente a los treinta y cinco minutos y veintiséis segundos del comienzo del filme.
} 
el segundo de los hermanos Panero 'marca la diferencia' en el entorno familiar. Todo está listo, por tanto, para que el hijo ausente cobre forma en la pantalla tomando la palabra con su rostro en primerísimo plano cuando se cumplen los cuarenta y nueve minutos y treinta y tres segundos del metraje. (Fig. 4) Y en esa intervención Leopoldo María no defrauda, sino que ratifica su 'diferencia' hablando de los veinte días en celdas de castigo que tuvo que soportar durante una estancia en la cárcel, experiencia que, según sus palabras, vivió como «un infierno $»^{24}$. Acto seguido, es Felicidad la que define a Leopoldo como «la gran complicación de mi vida », antes de que Michi enuncie una retahíla de desdichas familiares causadas por la falta de dinero sufrida con la orfandad, que los llevaron a vender buena parte de las propiedades heredadas y hasta la magnífica biblioteca paterna. Sin embargo, Felicidad retorna pronto a su segundo hijo para hablar del gran interés que sentía por la política que, según ella, utilizaba para desfogarse de tantas cosas como llevaba dentro. Entonces, en un inesperado cambio de escenario, la fachada del Liceo Italiano madrileño descrita con una lenta panorámica pasa a ocupar la pantalla, seguida por un plano general de Leopoldo y Michi descendiendo a contraluz por la escalinata del edificio. Segundos después, son Felicidad y sus dos hijos menores los que pasean por el patio del Liceo, para acabar sentados en un banco y seguir conversando.

Entramos así en el segmento clave del relato, con Leopoldo María como centro de atención. Y empieza la evocación de los años escolares de la infancia con la madre rememorando la frase "Leopoldo puede ser todo o nada» expresada por uno de sus profesores. Al escucharla, el aludido, como si de una premonición se tratase, apostilla: «Pues mira, yo creo que tenía mucha razón (...) en lo que he terminado es en el fracaso más absoluto. Lo que pasa es que yo creo que el fracaso es la más resplandeciente victoria ». Con esa contundencia, Leopoldo María va marcando el tono provocador y el territorio propio en que se va a instalar durante sus intervenciones. Precisamente, para definir con mayor exactitud la naturaleza real de las preocupaciones de su personaje, el realizador impondrá como pauta narrativa la alternancia de los segmentos de la charla maternofilial sostenida en los jardines del liceo con otros que muestran los parlamentos en solitario, siempre apoyados en citas de sus autores preferidos, que desgrana Leopoldo María acodado en la barra de un bar con un vaso de cerveza en la mano. Aislando al joven poeta, Chávarri logra trascender el ámbito familiar para centrarse en su personaje y en las preocupaciones y temas que lo obsesionan y que él comparte en buena medida : el alcohol como inductor de la soledad, la autodestrucción, el padre, etc. De vuelta al Liceo, cuando Felicidad y Michi recuerdan sus «hazañas» de colegial, su rebelde conducta con los castigos consiguientes y las ingeniosas ocurrencias, que hacían de él un pequeño líder entre sus congéneres, dan pie al poeta para que opine al respecto mostrando su contundente rebeldía: « el colegio es una institución penal en la que lo que nos enseñan es a olvidar la infancia. Me he rebelado siempre contra eso ». Y es a partir de esas evocaciones cuando Felicidad rememora los primeros poemas de su segundo hijo escritos con tres años y medio en un tono que ella califica de «bastante dramático». Dándole la réplica, el propio poeta recita dos de ellos conservados aún en su memoria. Con los recuerdos de los juegos de la infancia y los personajes y relatos inventados junto a su hermano Michi, la conversación

\footnotetext{
${ }^{24}$ Las tempranas inquietudes políticas de Leopoldo María hicieron que participara en la oposición al franquismo incluso antes de entrar en la Universidad. Posteriormente, como estudiante de Filosofía y Letras, tomará parte activa en la subversión lo que da lugar a sucesivas detenciones y estancias en la cárcel, aunque será la posesión de hachís la causante del juicio que lo lleva a cumplir una dura condena en la cárcel de Zamora. Todos los detalles de sus peripecias carcelarias los ha descrito José B. Fernández en El contorno del abismo, op. cit.
} 
entra en una deriva suavemente nostálgica que cierra otra afirmación radical de Leopoldo: « en la infancia vivimos y después sobrevivimos».

En realidad, esas palabras suponen el preámbulo de la gran andanada de acusaciones que está por llegar y que convierten el hasta entonces apacible diálogo maternofilial en una discusión en toda regla cuando Leopoldo María, expresándose en términos lacanianos, aborda el tema de lo que llama la leyenda épica familiar para pasar a desmantelar sin pudor la visión modélica ofrecida hasta entonces por la familia Panero. Sin ahorrar improperios, el poeta carga contra la brutalidad paterna, al tiempo que se muestra como víctima de la cobardía y la incomprensión de una madre que lo condenó a ser carne de psiquiátrico. Sus ataques a Felicidad son tanto más furibundos cuanto que consigue el apoyo de Michi, que se pone de su lado sin dudarlo, mientras la madre se defiende recordando a su hijo su impotencia frente a unos hábitos de vida que no era capaz de comprender y los angustiosos momentos pasados en sus visitas a la cárcel donde Leopoldo María estaba recluido ${ }^{25}$. Los más de diez minutos de discusión entre la madre y el hijo díscolo constituyen el clímax dramático del relato y significan la deconstrucción del retrato oficial de la familia Panero, que queda hecho trizas a partir del concienzudo repaso que el novísimo realiza de cada uno de los miembros que constituyen la unidad familiar. Nadie escapa a su mirada acusadora y, una vez cuestionados los padres, llega el turno de los hermanos Michi y Juan Luis, a los que tilda respectivamente de esquizofrénico y paranoico. Ambos, según Leopoldo María, lo habrían convertido en símbolo de aquello que más detestaban de ellos mismos.

Y mientras la conversación del trío familiar sigue en sordina, Chávarri empieza a preparar el cierre del relato y superpone a las imágenes de Leopoldo y Felicidad la voz de Michi para narrar las peripecias vividas por aquel durante sus actividades políticas. Poco después, él mismo habla del desencanto, respondiendo a la supuesta pregunta formulada por el director, un desencanto que niega argumentando que para tener ese sentimiento primero habría que haber estado encantado, y no fue su caso. Entonces retornan las imágenes de Castrillo y la añoranza de los veranos de la infancia, plasmada en una serie de fotografías de Felicidad con sus hijos sobre las que se superpone nostálgica la voz materna evocando la vida familiar y los hermosos versos del padre muerto. Todo queda solapado por la voz de Juan Luis, cuya figura tomada en plano medio avanza hacia la cámara en un largo travelling. Es el momento en que el vástago mayor recita un poema sobre su padre y comenta su esfuerzo por llevar el apellido familiar con dignidad, aunque su imagen vuelve a ser relevada por la de Leopoldo, quien (neutralizando las palabras del hermano mayor) insiste en que cada uno de los hijos se convirtió en sustituto del padre a su peor nivel, reflejando con ello la realidad de su figura. En ese crescendo autoinculpatorio es Michi el encargado de cerrar las intervenciones sentenciando lo que los tres hermanos representan: un irremediable "fin de raza astorgano", destinados como parecen estar a ser los últimos de su estirpe. $\mathrm{Y}$ el inserto inmediato de un poema epitafio dedicado al padre muerto parece sancionar esa certidumbre. Certidumbre que refuerza el inmediato giro narrativo posterior, que abrocha y clausura el relato retomando la imagen inicial de la estatua paterna envuelta en plástico, ahora más sombría y recortada sobre la fachada del palacio arzobispal de Astorga en la luz tenue del atardecer, mientras suenan los últimos compases de la sonata D 959 de Schubert.

\footnotetext{
${ }^{25}$ En el texto de sus memorias Felicidad narra su sorpresa y malestar cuando se sintió atacada por Leopoldo María en el jardín del Liceo Italiano durante el rodaje de la película : « cuando menos lo espero oigo la voz de Leopoldo María que empieza a atacarme. Y ahora no me importa más que defenderme. Qué importa la cámara, soy yo con mis viejos problemas, y me tiemblan las manos y los párpados de rabia ». En BLANC, Felicidad, Espejo de sombras, Barcelona, Argos, 1977, p. 243.
} 


\section{Reflexiones finales}

Frente a la lectura ortodoxa de la película como metáfora de la Transición, el análisis realizado hasta aquí permite defender una interpretación que, por todo lo dicho, encajaría más con el sentido originario de sus imágenes, el que encerraban las intenciones del realizador al abordar el proyecto del filme. Me refiero a su interés por ajustar cuentas con la institución familiar española tradicional y el papel que ella representó como transmisora de los valores del franquismo. Un ajuste de cuentas que encuentra su instrumento ideal no solo en el discurso demoledor que Leopoldo María desarrolla en el filme, sino también en todo lo que el propio personaje representaba ya a esas alturas, como enfant terrible que, desde su escritura y su conducta, se rebelaba insistentemente contra las convenciones del momento $^{26}$. No es de extrañar, por tanto, que Chávarri acabe convirtiéndolo en el pivote sobre el que gira el sentido final de la película. Una película que, en última instancia, pudo hacerse pública merced a la aprobación rotunda que el joven Panero manifestó, frente a las reticencias de los demás miembros de su familia, tras la proyección del montaje final hecha por el director ante todos ellos ${ }^{27}$. De ahí que, sin la presencia de Leopoldo María El desencanto no solo habría perdido la esencia de su complejidad significativa, sino que su misma existencia habría corrido peligro de ver la luz.

A día de hoy, reconocida la singular calidad de su obra poética como parte sustancial de la literatura española contemporánea, la reciente muerte del último de los Panero ha situado la película en una nueva dimensión, otorgándole el valor de documento excepcional que lleva inscritos los rasgos definitorios e inequívocos del poeta. Pese a su temprana edad -aún no cumplía la treintena- el joven Leopoldo María que encontramos en El desencanto deja entrever el genio único de su personalidad, marcada por un ideario vital reivindicador de la libertad más radical, basada en la defensa de la subjetividad y del individuo frente a las convenciones impuestas por el sistema, en cuyos márgenes el poeta sitúa voluntariamente su propio periplo existencial y su tarea creadora. Igualmente, la película permite entrever el amplio y variado mundo cultural derivado tanto de los intereses literarios del autor como de los temas que lo obsesionaron y que conforman su habla poética, tejida de palabras y frases de otros. Un habla definida como "una dicción hecha con tradición, a la que prolonga y lleva a nuevos lugares $»^{28}$ y todo ello, porque cada enunciado suyo $"$ se halla atrapado, se quiera o no, en el espacio multitudinario de la discursividad $»^{29}$. Como el propio discurso del poeta, la película no solo constituye un territorio complejo y rico en significados, sino que, con la extinción de la estirpe de los sujetos que le dieron vida, ha sido proyectada a la categoría de mito, y los mitos son eternos, también como objeto de estudio.

\footnotetext{
${ }^{26}$ Como ha señalado Túa Blesa, la figura del joven Panero ya a finales de los sesenta encerraba ya algo de « todo lo detestable para la sociedad de la época (y en mucho la de hoy): subversivo, drogadicto, bisexual, suicida, poeta que escribe contra las convenciones del momento ». Véase BLESA, Túa, Leopoldo María Panero, el último poeta, Madrid, Valdemar, 1995, p. 13.

${ }^{27}$ En FERNÁNDEZ, José B. El contorno del abismo. Vida y leyenda de Leopoldo María Panero, op. cit. Por su parte, Felicidad Blanc, en el libro de memorias publicado un año después del estreno de la película, comenta ese pase privado: « ... y, como siempre en todo lo que hago, la insatisfacción, el no acabar de encontrarme, el no ser yo del todo. Aquella mujer me irritaba ». En BLANC, Felicidad, Espejo de sombras, op. cit., p. 243.

${ }^{28}$ En BLESA, Túa, Leopoldo María Panero, el último poeta, op. cit., p. 14.

${ }^{29}$ En TALENS, Jenaro, « De poesía y su(b)versión (Reflexiones desde la escritura denotada 'Leopoldo María Panero) », en Panero, Leopoldo María, Agujero llamado Nevermore (Selección poética, 1968-1992), Madrid, Cátedra, 1992, p. 50.
} 


\section{Bibliografía de referencia}

ALVARES, Rosa y ROMERO, Antolín, Jaime Chávarri. Vivir rodando, Valladolid, Semana Internacional de Cine, 1999.

BLANC, Felicidad, Espejo de sombras, Barcelona, Argos Vergara, 1977.

BLANC, Felicidad, PANERO, Juan Luis, PANERO, Leopoldo $\mathrm{M}^{\mathrm{a}}$ y PANERO, José Moisés, El desencanto, Madrid, Elías Querejeta Ediciones, 1976.

BLESA, Túa, Leopoldo María Panero, el último poeta, Madrid, Valdemar, 1995.

EGEA, Juan, «El desencanto: la mirada del padre y las lecturas de la Transición », en Symposium, 2004, no 58, vol. 2, pp. 79-92.

FERNÁNDEZ, J. Benito, El contorno del abismo. Vida y leyenda de Leopoldo María Panero, Barcelona, Tusquets Editores, 2006.

LABANY, Jo, «Los fantasmas del pasado y las seducciones del psicoanálisis : El desencanto (Jaime Chávarri, 1976) », en Palacio, M., El cine y la transición política, Madrid, Biblioteca Nueva, 2011, pp. 73-85.

TALENS, Jenaro, « De poesía y su(b)versión (Reflexiones desde la escritura denotada 'Leopoldo María Panero') ", en Panero, Leopoldo María, Agujero llamado Nevermore (Selección poética, 1968-1992), Madrid, Cátedra, 1992, pp. 9-51. 